\title{
PENGARUH PEMBERIAN MAKANAN TAMBAHAN (MT) TERHADAP PENINGKATAN BERAT BADAN, KADAR HEMOGLOBIN (Hb) DAN ALBUMIN PADA IBU HAMIL KURANG ENERGI KRONIS
}

\author{
Sri Handayani Bakri \\ Akademi Kebidanan Muhammadiyah Makassar \\ e-mail: handayanibakri@gmail.com
}

\begin{abstract}
Abstrak
Pembangunan kesehatan dalam periode 2015-2019 difokuskan pada empat program prioritas yaitu penurunan angka kematian ibu dan bayi, penurunan prevalensi balita pendek Penelitian ini bertujuan untuk menilai besar perbedaan perubahan antara kelompok intervensi dan kelompok kontrol sebelum dan susudah pemberian makanan tambahan pada ibu hamil KEK. Jenis penelitian desain Quasi Eksperimental dengan rancangan pretestpostest control group design. Sampel dalam penelitian ini ibu hamil Kurang energi kronis (KEK) yang mengkonsumsi biskuit makanan tambahan dan tablet tambah darah (Fe) sebanyak 22 orang (kelompok intervensi) dan ibu hamil KEK yang hanya mengkonsumsi tamblet tambah darah ( $\mathrm{Fe})$ sebanyak 22 orang (kelompok kontrol) selama 3 bulan. Analisis data menggunakan uji Paired T Test dan uji independent test. Hasil penelitian menunjukan tidak ada perbedaan peningkatan berat badan dan kadar albumin antara kelompok intervensi dan kontrol sebelum dan sesudah pemberian biskuit makanan tambahan dan tablet Fe dengan $\mathrm{p}$ value $=0,096$ dan $p=0,066$. Ada perbedaan kadar hemoglobin antara kelompok intervensi dan kontrol sebelum dan sesudah pemberian biskuit makanan tambahan dan tablet Fe dengan nilai $p=0,021$
\end{abstract}

Kata Kunci: Biskuit makanan tambahan, ibu hamil kurang energy kronis peningkatan Berat badan, kadar hemoglobin dan albumin

\begin{abstract}
Health development in the period 2015-2019 is focused on four priority programs namely decreasing maternal and infant mortality, decreasing prevalence of short toddler. This study aims to investigate the changes between the two groups of chronic energy deficient pregnant mothers (intervention and control) before and after the introduction to suplememntary food. The research is set in quais-experimentation with pretest and posttest design of control group design. The samples are 22 pregnant mothers having chrionic energy deficient consuming supplementary food of biscuits and blood boosting tablet ( $\mathrm{Fe}$ ) (intervention) and other 22 pregnant mothers of similar condition were given blood boosting tablet only (control). The data were analyzed with Paired T Test and Independent test. The study indicates that no significant difference in weight gain and albumin level between the intervention and the control group before and after meal and the pill with the values $=0.96$ and $=0.066$ respctively. There is a significant difference in the hemoglobin level in the two groups before and after the supplementary food and Fe pills with a value of $p=0.021$
\end{abstract}

Keywords: Supplementary food biscuits, chronic energy deficient pregnant mothers, body weight, hemoglobin and albumin level

\section{PENDAHULUAN}

Pembangunan kesehatan dalam periode 2015-2019 difokuskan pada empat program prioritas yaitu penurunan angka kematian ibu dan bayi, penurunan prevalensi balita pendek (stunting), pengendalian penyakit menular dan pengendalian penyakit tidak menular (Kemenkes, 2016).

Riskesdas 2013, proporsi Wanita Usia
Subur (WUS) dengan risiko KEK masih tinggi yaitu $24,2 \%$ pada wanita hamil dan $20,8 \%$ pada wanita tidak hamil. Proporsi tertinggi di provinsi Nusa Tenggara Timur yaitu sebesar $45,5 \%$ pada wanita hamil dan $46,5 \%$ pada wanita tidak hamil, proporsi terendah di Provinsi Bali yaitu sebesar $10,1 \%$ pada wanita hamil dan $14 \%$ pada wanita tidak hamil. Di Provinsi Sulawesi Selatan yaitu sebesar 31,2\% pada wanita hamil dan $25,1 \%$ pada wanita 
tidak hamil.Kondisi ibu hamil Kurang Energi Kronis (KEK) dapat menjadi penyebab tidak langsung kematian ibu, berisiko menurunkan kekuatan otot yang membantu proses persalianan sehingga dapat mengakibatkan terjadinya partus lama dan perdarahan pasca salin dan anemia.

Risiko pada bayi dapat mengakibatkan terjadinya kematian janin (keguguran), prematur, lahir cacat, bayi berat lahir rendah (BBLR) pertumbuhan fisik balita pendek (stunting), otak dan metabolisme yang menyebabkan penyakit tidak menular diusia dewasa, yaitu kegemukan, penyakit jantung dan pembuluh darah, hipertensi, stroke dan diabetes (Kemenkes, 2014).

Dari hasil meta analisis bahwa BBLR dikaitkan dengan 2,5-3,5 kali lipat kemungkinan lebih tinggi terjadi wasting dan stunting. Masalah balita pendek menggambarkan adanya masalah gizi kronis, dipengaruhi dari kondisi ibu atau calon ibu. Penanggulangan masalah gizi dan kesehatan untuk meningkatkan kualitas sumber daya manusia paling tepat dilakukan pada masa menjelang dan saat prenatal (Cristian et al.,2015)

Memperbaiki gizi dan kesehatan ibu hamil merupakan cara terbaik dalam rangka mengatasi stunting. Ibu hamil perlu mendapat makanan yang baik, sehingga apabila ibu hamil dalam keadaan sangat kurus atau telah mengalami Kurang Energi Kronis (KEK), maka perlu diberikan makanan tambahan kepada ibu hamil tersebut (Amerta, 2015)

PMT dengan keseimbangan energi protein merupakan pilihan yang tepat. Produk PMT yang akan diberikan sudah memperhatikan aspek cita rasa, kepraktisan, daya simpan kemudahan dalam penyajian dan mudah mendapatkan bahannya dimasyarakat karena masyarakat sudah mengenalnya (Yunita, 2013). Oleh karena itu penelitian ini bertujuan untuk diketahuinya besar perbedaan perubahan antara kelompok intervensi dan control sebelum dan sesudah pemberian makanan tambahan pada ibu hamil kurang energi kronis yang mendapat tablet tambah darah.

\section{METODE}

Penelitian ini dilaksanakan pada bulan April - Juni 2017. Lokasi di PUSKESMAS kota Pare-Pare Sulawesi Selatan. Rancangan Penelitian ini menggunakan "Quasy eksperiment "dimana bentuk rancangan/desain yang digunakan adalah Pretest-Postest control group design. dalam penelitian ini yang termaksud dalam kelompok intervensi adalah ibu hamil Kurang Energi Kronis yang diberi biskuit makanan tambahan dan tablet tambah darah $(\mathrm{Fe})$ dan kelompok Kontrol adalah ibu hamil Kurang Energi Kronis yang hanya mendapat tablet tambah darah (Fe).

Populasi dalam penelitian ini adalah seluruh ibu hamil yang datang melakukan pemeriksaan di enam PUSKESMAS Kota Pare-Pare. Sampel adalah ibu hamil KEK, cara pemilihan sampel dengan metode Purposive Sampling. Dengan kriteria inklusi dan ekslusi serta droup out yang telah ditentukan.

Pengumpulan data dengan pengukuran berat badan, pemeriksaan kadar hemoglobin dan pemeriksaan kadar Albumin dengan metode brom - Cresol Green (BCG)

Untuk menguji data berdistribusi normal/tidak menggunakan uji statistik normalitas (test of normality). Taraf signifikan $(\alpha=0,05)$. Jika $\alpha>0,05$, maka Ho diterima yaitu data berdistribusi normal. Uji analisis menggunakan uji Man Whitney, pairet t-test dan independent $t$ - test 


\section{HASIL DAN PEMBAHASAN}

Tabel 1. Perubahan Berat Badan antara kelompok intervensi dan kontrol pada Pemberian Biskuit Makanan Tambahan ibu hamil KEK

\begin{tabular}{|c|c|c|c|c|c|c|c|c|}
\hline \multirow{2}{*}{ Variabel } & & \multicolumn{2}{|c|}{ Sebelum (Pre) } & \multicolumn{2}{|c|}{ Sesudah (Post) } & \multirow{2}{*}{ p } & \multirow{2}{*}{ Selisih } & \multirow{2}{*}{$\mathbf{P}$} \\
\hline & & Mean & $\pm \mathrm{SD}$ & mean & $\pm \mathrm{SD}$ & & & \\
\hline Berat & Intervensi & 44.868 & 2.5015 & 52.605 & 3.3783 & 0.001 & 7.737 & 0021 \\
\hline Badan & Kontrol & 46.191 & 2.6414 & 53.073 & 4.7124 & 0.032 & 6.882 & 0.021 \\
\hline
\end{tabular}

Sumber : Data Primer, 2017

Tabel 2. Perubahan Kadar Hemoglobin antara kelompok intervensi dan kontrol pada pemberian biskuit makanan tambahan ibu hamil KEK

\begin{tabular}{llllllll}
\hline \multirow{2}{*}{ Variabel } & & \multicolumn{2}{c}{ Sebelum $($ Pre) } & \multicolumn{2}{c}{ Sesudah (Post) } & \multirow{2}{*}{ Selisih } & \multirow{2}{*}{ P } \\
& & Mean & \pm SD & mean & \pm SD & & \\
\hline \multirow{2}{*}{ Hemoglobin } & & & & & & & \\
& Intervensi & 10.155 & 1.2211 & 11.214 & 0.8999 & 1.0595 & \multirow{2}{*}{0.021} \\
& Kontrol & 10.968 & 1.0214 & 11.277 & 0.9646 & 0.3088 & \\
\hline
\end{tabular}

Sumber : Data Primer, 2017

Tabel 3. Perubahan kadar Albumin antara kelompok intervensi dan kontrol pada pemberian biskuit makanan tambahan ibu hamil KEK

\begin{tabular}{lllllllll}
\hline \multirow{2}{*}{ Variabel } & \multicolumn{2}{l}{ Sebelum (Pre) } & \multicolumn{2}{l}{ Sesudah (Post) } & & & \\
& & Mean & \pm SD & mean & \pm SD & P & Selisih & P \\
\hline \multirow{2}{*}{ Albumin } & Intervensi & 4.1773 & 0.3545 & 3.65 & 0.3827 & 0,066 & 0.5273 & \\
& Kontrol & 3.9864 & 0,31517 & 3.605 & 0.2299 & 0,635 & 0.3814 & 0.090 \\
\hline
\end{tabular}

Sumber : Data Primer, 2017

Berdasarkan Tabel 1 perubahan berat badan pada pemberian biscuit makanan tambahan antara kelompok intervensi dan control menunjukkan bahwa terdapat perbedaan perubahan berat badan antara kedua kelompok dengan nilai $p=0,021$. Selanjutnya berdasarkan Table 2 perubahan kadar hemoglobin antara kelompok intervensi dan control juga menunjukkan terdapat perbedaan perubahan kadar hemoglobin antara kedua kelompok dengan nilai $p=0,021$. Namun berdasarkan Tabel 3 perubahan kadar albumin antara kelompok intervensi dan control tidak menunjukkan perbedaan perubahan kadar albumin dengan nilai $\mathrm{p}=0,090$.

Berdasarkan penelitian ini didapatkan bahwa terdapat perbedaan perubahan berat badan dan kadar hemoglobin dengan nilai $\mathrm{p}$ masing- masing $\mathrm{p}=0,021$ dan pada pemeriksaan kadar albumin tidak terdapat perbedaan bermakna dengan nilai $\mathrm{p}=0,066$. Hal ini sejalan dengan penelitian yang dilakukan oleh Chandradewi (2015), hasil uji statistic paired t- test, diperoleh nilai sig 0,000 $(p<0,05)$ yang berarti bahwa pemberian makanan tambahan memberikan pengaruh yang signifikan terhadap kenaikan berat badan ibu hamil KEK di Labuan Lombok Kabupaten Lombok Timur.

Selama masa kehamilan kebutuhan zat gizi yang diperlukan untuk metabolisme tubuh baik pada Ibu dan janin dalam kandungan meningkat. Oleh karena itu pada masa kehamilan asupan zat gizi yang diperlukan juga meningkat untuk pertumbuhan dan perkembangan janin juga penambahan besarnya organ kandungan, perubahan komposisi dan metabolisme tubuh ibu dan janin. Ibu hamil yang mengalami kekurangan asupan zat gizi dan berstatus gizi buruk maka berpeluang besar melahirkan bayi dengan BBLR (Cunningham, 2005).

Proses biologik yang terjadi selama kehamilan ditandai dengan pertambahan berat 
badan yang berasal dari beberapa komponen. Perubahan yang terjadi selama kehamilan terukur dalam kenaikan berat badan ibu. Untuk itu agar bayi yang dilahirkan dalam kondisi normal membutuhkan energi dan zat gizi optimal yang diperoleh melalui ibu. Ibu hamil dengan cukup energi dan asupan zat gizinya akan naik berat badannya sesuai umur kehamilan dan bayi lahir sehat. Apabila proses kehamilan diawali dengan kondisi gizi kurang, maka kenaikan berat badan selama hamil harus juga mempertimbangkan deficit berat badan, artinya kenaikan berat badan pada ibu hamil KEK harus lebih besar dibandingkan ibu hamil normal (Fraser, 2009).

Pengenceran darah (hemodilusi) pada ibu hamil sering terjadi dengan peningkatan volume plasma sekitar 30-40\%, peningkatan sel darah merah bertambah sebanyak 18-30\% dan hemoglobin bertambah sebanyak $19 \%$. Secara fisiologis, hemodilusi terjadi untuk membantu meringankan kerja jantung. Hemodilusi terjadi sejak usia kehamilan 10 minggu dan mencapai puncaknya pada kehamilan 32-36 minggu. Bila hemoglobin ibu sebelum hamil berkisar $11 \mathrm{gr} \%$, maka dengan terjadinya hemodilusi akan mengakibatkan anemia fisiologis dan $\mathrm{Hb}$ ibu akan menurun menjadi 9,5-10,0 gr\% (Saryono, 2009).

Pemberian biskuit makanan tambahan ibu hamil (PMT) dapat meningkatkan kadar hemoglobin karena mengandung makro dan mikronutrien yang dibutuhkan ibu dan janin sehingga mampu mengatasi masalah anemia pada ibu hamil (Hermansyah dkk., 2014).

Kebutuhan albumin pada ibu hamil lebih banyak dari sebelum hamil sehingga perlu diperhatikan, karena pada ibu hamil albumin bermanfaat membantu dalam metabolisme dan pembentukan jaringan yang baru pada tubuh termasuk janin yang ada dalam kandungannya. Sedangkan pada perempuan yang sedang bersalin selalu mengeluarkan darah pada saat persalinan dan pada perempuan reproduktif mengeluarkan darah tiap bulannya pada saat menstruasi sehingga ada kemungkinan albumin hilang bersamaan dengan keluarnya darah. Oleh karena itu, perempuan lebih rentan terjadi hipoalbumin (Wahyuni dkk., 2014)

\section{KESIMPULAN}

Dari hasil penelitian ini dapat disimpulkan bahwa pemberian makanan tambahan pada kelompok intervensi ibu hamil KEK dapat meningkatkan kadar hemoglobin tiga kali lebih besar dari kelompok kontrol dan memberi pengaruh terhadap perbedaan perubahan berat badan. namun tidak berpengaruh secara signifikan terhadap kadar albumin. Saran bagi pemerintah terkait dan tenaga kesehatan agar lebih banyak melakukan pemantauan terhadap ibu hamil kurang energy kronis, agar kehamilan dapat berlangsung dengan normal dan tidak berlanjut kepada terjadinya komplikasi kehamilan.

\section{REFERENSI}

1) Amerta D.I. (2015). Hubungan pemberian makanan tambahan pemulihan dengan kadar hemoglobin dan kenaikan berat badan ibu hamil kurang energy kronik (studi di wilayah kerja puskesmas Jelbuk kabupaten Jember

2) Chandradewi. (2015). P engaruh Pemberian Makanan Tambahan Terhadap Peningkatan Berat Badan Ibu Hamil KEK di Wilayah Kerja Puskesmas Labuan Lombok. Jurnal Kesehatan Prima Vol.9. No 1.Februari 2015

3) Christian P., Lee S.E., \& Angel MD. (2015). Risk of childhood undernutrition related to small-for-gestational age and preterm birth in low-and middle-income countries. International journal of epidemiology. 2013;42(5):1340-1355.

4) Cunningham. (2005). Obstetri Williams Vol. 1 Ed. 21.EGC. Jakarta Fraser M. ( 2009). Buku Ajar Bidan Myles. EGC. Jakarta

5) Hermansyah dkk. (2014). Pengaruh ekstrak daun kelor terhadap asupan dan berat badan ibu hamil pekerja sektoral informal

6) Herta M. H. (2012). Suplementasi multi mikronutrien dibandingkan Fe- asam folat terhadap kadar HB pada ibu hamil. Gizi Klinik Indonesia, 35.

7) Kemenkes. (2016). Pusat Data dan Informasi, Jakarta

8) Kemenkes. (2014). Pedoman Gizi Seimbang. Jakarta: Kementrian Kesehatan RI. Saryono. (2009).Biokimia Respirasi.Nuha Medika. Yogyakarta

9) Wahyuni dkk. (2014). Pengaruh Pemberian (Albumin) Ikan Kutuk Terhadap Peningkatan Kadar Albumin Pada Pasien Post Operasi Dengan Hipoalbumin di Ruang Graham Hita 
AL-IQRA MEDICAL JOURNAL : JURNAL BERKALA ILMIAH KEDOKTERAN

e-ISSN : 2549-225X. Vol. 4 No. 1, Februari 2021, Hal. 19-23

RSUD.dr. ISKAK Tulungan.

10) Yunita. (2013). Asupan energi dan protein Program Pemberian Makanan Tambahan Pemulihan pada Ibu hamil KEK. UNPAD journal, 9. 